\title{
New zircon U-Pb LA-ICP-MS ages from the Dom Feliciano belt magmatism in Uruguay: Guazunambí and Arroyo Gutiérrez Granites
}

\author{
FORT, $\mathrm{S}^{1}$. PEEL, E. ${ }^{1}$ \\ ${ }^{1}$ Facultad de Ciencias, Universidad de la República. Iguá \\ 4225 CP 11400, Montevideo, Uruguay (*correspondence: \\ fortsantiago92@gmail.com)
}

The Dom Feliciano Belt (DFB) extends for $1000 \mathrm{~km}$ from South of Brazil to Southeastern Uruguay. In Uruguay the DFB limits to the East with the Atlantic Ocean and to the West with the Nico Pérez Terrane (NPT) which is considered by many authors as part of Río de la Plata craton. DFB was formed during the Brasiliano orogenic cycle (Neoproterozoic) as a result of the interaction between Rio de la Plata, Congo and Kalahari cratons, during the amalgamation of Gondwana [1]. Granitic magmatism is a characteristic feature in the DFB, with a numerous bodies emplaced all along the belt. In the last years the ages of this magmatism to the west of the Sierra Ballena shear zone [2] was constrained between $634 \pm 7 \mathrm{Ma}$ [3] and $583 \pm 8 \mathrm{Ma}$ [4]. The Guazunambí and Arroyo Gutiérrez granites have been assumed to belong to this intrusive magmatism developed on the late stages of the evolution of the DFB. In order to confirm this hypothesis, new zircon U-Pb LA-ICP-MS data is presented here: (1) Guazunambí granite: 22 zircon grains were analyzed. A concordant crystallization age was obtained of $620,1 \pm 4,7 \mathrm{Ma}$ and inherited ages of $3079 \pm 18$ Ma, $2974 \pm 17$ Ma y $2074 \pm 17$ Ma. (2) Arroyo Gutiérrez granite: 24 zircon grains were analyzed; a concordant crystallization age of $592,9 \pm 2,4$ Ma was obtained, with none inheritage ages. These results shows that these bodies belong to this magmatism, and were emplaced during DFB formation. The differences on inherited ages point that the source associated to each body have differences. While Arroyo Gutiérrez granite seems to only shows ages associated with the rocks formed during DFB evolution, the Guazunambí granite displays a range of inherited ages that only appears on the NPT, suggesting that the source for this granite involves also this terrane.

[1] Fragoso Cesar, A. R. S. (1980). XXXI Cong. Bras. Geol, (5), 2879-2892. [2] Gómez Rifas, C. (1995). Tese de Doc. Programa de Pós-Graduação Em Geotect. USP, 1-262. [3] Lara, P., et al., (2017). Lithos, 277, 178-198. [4] Gaucher, C., et al., (2008). Precam,. Research, 167(1-2), 150-170. 